\title{
SOCIAL NETWORKING USAGE QUESTIONNAIRE: DEVELOPMENT AND VALIDATION IN AN INDIAN HIGHER EDUCATION CONTEXT
}

\author{
Dr. Savita GUPTA \\ Faculty of Education \\ Lovely Professional University \\ Phagwara, India \\ Liyaqat BASHIR \\ Department of Education \\ Lovely Professional University \\ Phagwara, India
}

\section{ABSTRACT}

The concept of social networking has received much attention from academia over the last decade in India. Widespread research has conceptualized the term social networking with almost all of the studies either conceptual or based on case studies. This paper is an attempt to clarify the construct of social networking by developing a reliable and valid questionnaire measuring social networking usage. 420 university students from 6 universities in Jammu and Kashmir were surveyed via a random sampling technique and factor analysis carried out on their responses. The findings revealed that social networking usage can be decomposed into four factors: academic; socialization; entertainment and informativeness. The internal consistency indices, Cronbach's alpha of social networking usage $(a=.830)$ indicates good internal reliability. The findings revealed that the newly developed questionnaire has significant psychometric features.

Keywords: Social networking usage, university students, scale development, factor analysis.

\section{INTRODUCTION}

Social networking usage refers to online space that is used by students to connect, share, communicate, establish or maintain connection with others for academic, entertainment, socialization etc. Social networking as a communication medium is rising quickly, mostly in the prosperous increase of applications for mobile devices. Especially young adults are becoming familiar with sharing their everyday life and experiences, keeping in touch with teachers, friends, and family online and talking about their interests (Leung 2002; Morahan-Martin \& Schumacher 2003). The past few years have observed an explosion of social networking such as Twitter, Facebook etc. which have added a fresh social dimension to the web. There have been a rapidly increasing number of online connections among groups of persons who share similar interests, though they are assembled in an absolute space (Wilson et.al 2002). A number of social networking sites (e.g., Twitter, Facebook, LinkedIn, Google plus, Orkut, Google plus) have employed dynamic social contexts in which online communities can be made and continued easily by the facilitation of communications and social connections among users. Such networking opportunities help make groups, communities and people with shared interests remain more associated.

In recent years, social networking sites have been the prevalent tools for online communication combining the interpersonal and mass communication competences 
together (Pempek, et al; 2009; Boyd \& Ellison, 2007). Social networking sites like Twitter, LinkedIn, and Facebook support online groups that allow users to broadcast and construct their profile information, and interact with others by sending personal and public messages, playing games, and sharing photos (Pempek, Yermolayeva, \& Calvert, 2009; Boyd \& Ellison, 2007). Social networking sites facilitate individuals, making new online friends and acquaintances, and to maintain pre-existing social connections (Ellison, Lampe, \& Steinfield, 2007).

The majority of users of the social networking sites are young people (14 to 25 year olds) who were named by Prensky (2001), as "Digital Natives" especially represented at the moment by students in higher education. These digital natives often use social networking sites to connect with their offline peers to strengthen their existing relations rather than building new relationships, (Ellison, Steinfield, \& Lampe, 2007; Waechter, Reich, Espinoza, \&, Subrahmanyam, 2008). Social networking sites might provide a potential medium to attain deeper online knowledge than conventional e-learning platforms, if educationallyfocused actions can be closely integrated into the use of social networking sites (Srivastava, 2012). Moreover, social networking sites allow students to highlight their experiences and talents, and communicate and express themselves better.

The advantages of using social networking sites for educational purpose are far ranging. A study stated that the use of social networking tools improved student's learning opportunities, allowed for real-time communication outside the classroom, fostered collaborative opportunities, and enhanced creativity (George, \& Dellasega, 2011). Learners can watch educationally relevant videos or exchange information about what they have watched and learned, and then join online to further discuss with teachers. Even the teachers can learn from the students during social networking interactions. Similarly, a teacher can supervise students while they are learning, reflecting, sharing, interacting and summarizing discussions. Social networking sites provide a forum to contact peers and teachers from wherever they are, offering the flexibility of extended duty hours. Some social networking sites, especially Facebook, features may boost students to involve in social and creative learning progressions that extend beyond traditional educational settings and institutions (Wiberg, 2007). This provides added benefit to access extensive and different sources of information and opportunities for communication (Anderson, \& Dron, 2007). At present, a lot of educational institutions are making use of the advantages of social networks in the teaching and learning process. According to the results of the study conducted by the U.S. Department of Education (2009), the classes using social networks or online systems were found to be more effective than the classes using the traditional face-to-face instruction.

Given the collaborative and interactive nature that describes social networking has tremendous potential for the field of education. Universities and Colleges are beginning to embrace social networking and understanding the potential power and implications for using it in education. Blankenship (2010) indicated that the usage of social networking in education results in many benefits, such as greater student interest, greater student engagement, more responsibility for their education and students take more control over their education. It also indicates that social networking sites support educational activities by creating interaction, collaboration, and active participation. In similar way Abdulahi et al., (2014) \& Ahn, (2011) noted that social networking and media tools offer students the opportunity to communicate, access information, get in touch, chat and research. Further Deng and Tavares (2013) noted that social networking has become an integral part of our student's social life; it is now seen as a learning platform that could be employed to increase student performance and engagement.

However, some studies have shown that social networking usage can lead to a multiplicity of negative consequences like reduction in academic performance, decrease in offline community engagement, and relationship problems (Griffiths \& Kuss, 2011, Unachukwu et.al 2016). To examine social networking usage, there seems to be a need for a reliable and valid questionnaire to be developed. So, the sole purpose of this study is to bridge this 
gap and validate the developed questionnaire regarding its psychometric properties by specifying its accuracy and consistency of measurement.

\section{PREVIOUS MEASURES OF SOCIAL NETWORKING USAGE}

After studying the previous literature of social networking usage it was found that several measurements had been developed to investigate the social networking usage. One instrument, developed by Pornsakulvanich, et.al (2013), explored six components as, friendship, passing time, relationship maintenance, in trend, entertainment and relaxation. This scale was used to assess a degree to which individuals graded their specific aims for using social networking sites. Moreover, a quantitative survey questionnaire on social networking was standardized by Eid, et al; (2016), which explored four categories as enjoyment and entertainment, file sharing, content creation, online discussion, and chatting. Moreover, Jenkins-Guarnieri, et al (2013) standardized a scale on online social media use that assesses the daily routines of users, combination of the social behavior, along with the emotional connection and importance of to this use, but this scale is not suitable to measure our construct. In the Indian context, Bolar (2009) developed a questionnaire based on 28 statements, on a 5-point Likert scale ( 1 = Strongly Disagree, 5 = Strongly Agree). This scale is actually based on the purpose of social networking sites usage. In addition, Shi et al (2014), standardized a scale on social networking sites usage. The scale contains two subscales; an affective experience scale and a featured usage scale. Another instrument by Shin et al (2017) aimed to measure the social network site use motives of college students. The scale consists of $\mathbf{3 0}$ items written in Korean, each representing one of the six subscales, which are information, enjoyment, social, mood regulation, pastime, and conformity. Different authors standardized their own scales by using exploratory factor analysis (EFA).

However, so for nobody has completed a confirmatory factor analysis (CFA), or provided detailed psychometric statistics such as test-retest reliability coefficient estimates. Other authors have provided only vaguely-defined measures (Shin, et.al 2017), and did not offer detailed psychometrics (e.g., Eid, et al. 2016; Shy, et al. 2014 \& Pornsakulvanich, et al. 2013), making evaluations of their instruments difficult. Neither have they provided any comprehensive documentation of how they progressed through the formal procedures for scale development and validation. Moreover, Shy, et al. (2014), points out to the lack of association with other social networking sites questionnaires and examination of the testretest reliability. In addition, Shin et al (2017) used only self-reported data to assess SNS addiction levels, and the time spent using SNSs was not included in the assessment of SNS addiction. Jenkins-Guarnieri, et al. (2013) used a nonrandom sample, composed of voluntary participants, which may have produced significant selection biases.

There are also scales which have been developed and used to determine the usage of specific social networking sites; in particular Facebook. The Facebook intensity scale developed by Ellison, et al (2007)_contains two self-reported assessments intended to assess the degree to which respondents are keenly involved in Facebook, with six attitudinal items aiming to measure the degree to which respondents are passionately engaged in using Facebook and the amount to which Facebook is integrated into their everyday practices. Moreover, Andreassen et al (2012) standardized a scale on Facebook addiction based on 18 items with six elements (modification, salience tolerance, mood, withdrawal, relapse, and conflict). Ross et al (2009) standardized a Facebook Questionnaire that includes attitudes associated with Facebook, posting of individuallyrecognizing, information, and basic use of Facebook.

Ellison, et al (2007) conducted neither a confirmatory factor analysis (CFA) nor an exploratory factor analysis (EFA) on their instrument, and they did not provide detailed psychometric statistics such as convergent validity, discriminate validity, and test-retest reliability coefficient estimates. In the study of Ross et al (2009), the low internal consistency, may have caused underestimation of associations among theories. Moreover, Andreassen et al (2012) developed a scale, and provided detailed psychometric statistics, 
but the statements of the scale have too much ambiguity. Most of the research on Facebook usage thus far has used psychometrically-weak measures. Based on scale development theory (DeVellis, 2016), even the most recent research published in peer-reviewed journals have used somewhat lacking assessment measures to operationalize Facebook use. Additionally, much previous research in this has poor reliability estimates and high measurement error. None of these studies conducted rigorous psychometric analyses before using the data collected from their new measures to answer subsequent research questions.

Whereas a number of social networking scales have been developed, no such scale has been constructed specifically for our context. This study will fill the gap, and present a set of items which have been checked to have direct applicability to the Indian context. Because social networking usage has positive and negative consequences for university students, it is important for researchers to ascertain the university students' level of social networking usage. The review of the literature demonstrates that numerous studies have been done on this said construct but it is essential to confirm the validity of the constructs even if well-established measures are involved (Hair, et al., 2010). With the purpose of decreasing error by improving reliability and validity, better explanations and more accurate predictions can be made through multivariate statistical analysis. Various methods can be found under multivariate methods and depending on the methods of analysis, different types of statistical approaches can be used (Hair, et al., 2010). This study explicitly explores the social networking usage behavior among university students by following the highly reliable and valid scale development procedures of Hinkin (1995) and Churchill (1979).

\section{ITEM GENERATION PROCEDURE}

Based on our theoretical framework, we developed statements related to social networking usage. The generated statements intended to capture social networking usage of university students. Therefore, the summated assessment procedure proposed by Likert (1932) was used to develop the present scale. We identified 56 items related to social networking usage from previously developed instruments. These were aligned so they could all be answered using a 5-point Likert scale, with each statement rated on five anchors, (Always=5, Often=4, Sometimes=3, Rarely=2 and Never=1). The above extensive literature review guided us in producing an instrument with robust psychometric properties to measure the social networking usage of university students. It is much helpful for these items to be strong when used in a Likert format (DeVellis, 2016).

\section{Respondents}

To pilot the instrument, a group of respondents were recruited from 6 universities from Jammu and Kashmir, India. The total number of respondents in the study comprised 420 university students (i.e. $\mathbf{N}=420$ ), 220 male and 200 females, who were selected via random sampling technique. Initially, out of three divisions in Jammu and Kashmir, two divisions were selected randomly. Then universities in the division were selected randomly. From those universities several students were picked up randomly as participants. The sample comprises of students from different universities from Jammu and Kashmir covering postgraduate students particularly in the age range of 21-23. There was an equivalent representation of students from different streams such as sciences and engineering, management and commerce and arts \& humanities, selected by employing the simple random sampling technique. The aim of the study was conferred and the concerned higher authorities were contacted. Participants were motivated to complete the questionnaire with humble request. In the initial study $\mathbf{4 4 2}$ questionnaires were distributed, and merely 433 participants' responses were returned. The returned questionnaires were carefully checked for comprehensiveness, respondent detachment, misplaced outliers and values (Hair et al. 2010). Eleven questionnaires were rejected due to missing information. The final and scoured dataset contained of 420 responses out of 420 students, 220 male and 200 females. 


\section{Content Validity}

Content validity was established at the time of developing a preliminary draft of the research instrument by carrying out critical discussions with nine experts who reviewed, 56 statements selected for the first draft. The contents of each item were critically examined by these experts to review the suitability and relevancy of these items for a social networking usage questionnaire. Only those statements were retained for the second draft which had at least $75 \%-85 \%$ agreement among experts with regard to relevance of items. The experts were of the opinion that the remaining 42 statements were completely satisfactory and relevant to measure the social networking usage of university students in India, confirming the social networking usage questionnaire was a sufficiently valid instrument for piloting.

\section{Exploratory Factor Analysis}

The next step in the refinement stage was to conduct exploratory factor analysis (EFA). EFA provides information about the amount of constructs required to represent the data. Exploratory factor analysis helps discover the probable original factor construction of a set of observed variables not having imposing a predetermined structure on the consequence (Child, 1990). We explored the factors of social networking usage through exploratory factor analysis. Numerous iterative cycles of factor analysis were conducted on the data set. The total variance and numbers of factors extracted were examined after each iteration. Factors with low communalities which didn't correlate were deleted with the purpose of refining the factor structure to get a matrix with clearer loadings. We used the principal component matrix (PCA), and for rotation used the Varimax method. With this, we checked the factorability of the 42 statements. After performing the exploratory factor analysis, the Kaiser-Meyer-Olkin (KMO) measure of sampling adequacy was calculated .888. According to Tabachnick and Fidell (1996) the minimum Kaiser-Meyer-Olkin (KMO) for a good factor structure should be $\mathbf{0 . 6 0}$. A negligible significance level was shown by Bartlett's test of sphericity. Both measures suggest that the sample data were adequate for the performing factor analysis. The detailed report is presented in Table 1.

Table 1

\begin{tabular}{l|l|r}
\hline \multicolumn{2}{c}{ KMO and Bartlett's Test } \\
\hline \multicolumn{2}{|c|}{ Kaiser-Meyer-Olkin Measure of Sampling Adequacy } \\
\hline \multirow{3}{*}{ Bartlett's Test of Sphericity } & Approx. Chi-Square & .888 \\
\cline { 2 - 3 } & Df & 2929.600 \\
\cline { 2 - 3 } & Sig. & $\mathbf{2 7 6}$ \\
\hline
\end{tabular}

Factor Structure: The factor analysis indicates a five factor structure, explaining $53.20 \%$ of the variance, with all items loading above $\mathbf{. 4 0}$. (Acceptable item loading of above sample 350 is 0.40 (Heir et al 2007). The first factor comprised the academic items (7 items), the second factor comprised items relating to the socialization (6 items), the third factor consisted of the items related to entertainment (4 items), the fourth factor consisted of the items related to informativeness ( 3 items), and the fifth factor related to constraints (4 items). The items and their factor loadings are presented in Table 2. 
Table 2. Statements of Social Networking Usage Questionnaire and Their Factor Loadings

$\begin{array}{lcc}\text { Items } & \text { Statements } & \text { Factor } \\ & & \text { Loadings } \\ \text { mension: One } & \text { Academic } & \end{array}$

Dimension: One

Academic

.670

\begin{tabular}{|c|c|c|}
\hline Item 39 & I use social networking sites to solve my academic problem. & .670 \\
\hline Item33 & I use social networking sites to do research work. & .648 \\
\hline Item28 & I use social networking sites for online academic group discussion. & .646 \\
\hline Item35 & $\begin{array}{l}\text { I communicate with my friends via social networking sites for preparation of } \\
\text { exam. }\end{array}$ & .645 \\
\hline Item38 & I use social networking sites for collaborative learning. & .560 \\
\hline Item 34 & I use social networking sites to learn about my curricular aspect. & .530 \\
\hline Item 14 & I use social networking sites to seek help from my teachers. & .499 \\
\hline \multicolumn{3}{|c|}{ Dimension: Two } \\
\hline Item08 & I use social networking sites to become more sociable. & .680 \\
\hline Item25 & I use social networking sites to create my social identity. & .673 \\
\hline Item26 & I prefer using social networking sites to attending social gathering. & .622 \\
\hline Item10 & I use social networking sites for strengthening interpersonal relationships. & .543 \\
\hline Item11 & I use social networking sites to keep in touch with my relatives. & .522 \\
\hline Item27 & I use social networking sites to get information regarding current social events. & .512 \\
\hline \multicolumn{3}{|c|}{ Dimension: Three $\quad$ Entertainment } \\
\hline Item32 & I use social networking sites for sharing pictures. & .686 \\
\hline Item42 & I use social networking sites to look at funny sharing. & .683 \\
\hline Item37 & I use social networking sites for watching movies. & .587 \\
\hline Item36 & I use social networking sites to get relief from academic stress. & .577 \\
\hline \multicolumn{3}{|c|}{$\begin{array}{ll}\text { Dimension: Four } & \text { Informativeness } \\
\end{array}$} \\
\hline Item30 & I use social networking sites for reading news. & .714 \\
\hline Item23 & I use social networking sites to share new ideas. & .626 \\
\hline Item16 & I use social networking sites for getting jobs related information. & .422 \\
\hline \multicolumn{3}{|c|}{ Dimension: Five Constraints } \\
\hline Item21 & $\begin{array}{l}\text { I face difficulty in finding exact information for academic via social networking } \\
\text { sites. }\end{array}$ & .709 \\
\hline Item12 & Compulsive usage of social networking sites is a problematic issue. & .664 \\
\hline Item19 & $\begin{array}{l}\text { I usually postpone my academic task for spending more time on the social } \\
\text { networking sites. }\end{array}$ & .621 \\
\hline Item17 & $\begin{array}{l}\text { While using social networking sites it is difficult for me to concentrate on my } \\
\text { studies. }\end{array}$ & .582 \\
\hline
\end{tabular}

\section{CONFIRMATORY FACTOR ANALYSIS}

The confirmatory factor analysis by Sorbom, \& Joreskog (2004) is a different case of Structural Equation Modeling which is called the "linear structural relationship model." Confirmatory factor analysis is a handy statistical process for providing validity evidence (Gerbing, \& Hunter 1982), which is applicable when constructs are assessed with several items, when the scale statements have a linear association to the scale total or average, and when an examiner has an a priori knowledge of which statements measure which constructs. Confirmatory factor analysis is a statistical method 
used to confirm the factor structure of a set of observed variables. CFA permits the researcher to test the hypothesis that an association with the underlying latent constructs and observed variables exists (Suhr, 2006).

Using the SPSS Amos 22 version, the confirmatory factor analysis was applied to the five factors extracted in the exploratory factor analysis. The indices of the model were (CMIN/DF=2.193, Comparative Fit Index (CFI) =.887, Goodness Fit Index (GFI) =.926, AGFI=.904, Root Mean Square of Approximation (RMSEA) $=.053$, and Chi-square $=320.240(p>0.01)$. The final CFA model is on four factors. The inspection of the results revealed that the factor loadings of three statements of that factor were below the threshold value. As this only left one statement, and because it is accepted that any factor with less than three statements should be deleted, the four statements of constraints factor was deleted (Hair et al; 2010). Figure 1 provides a holistic view of the confirmatory factor analysis model.

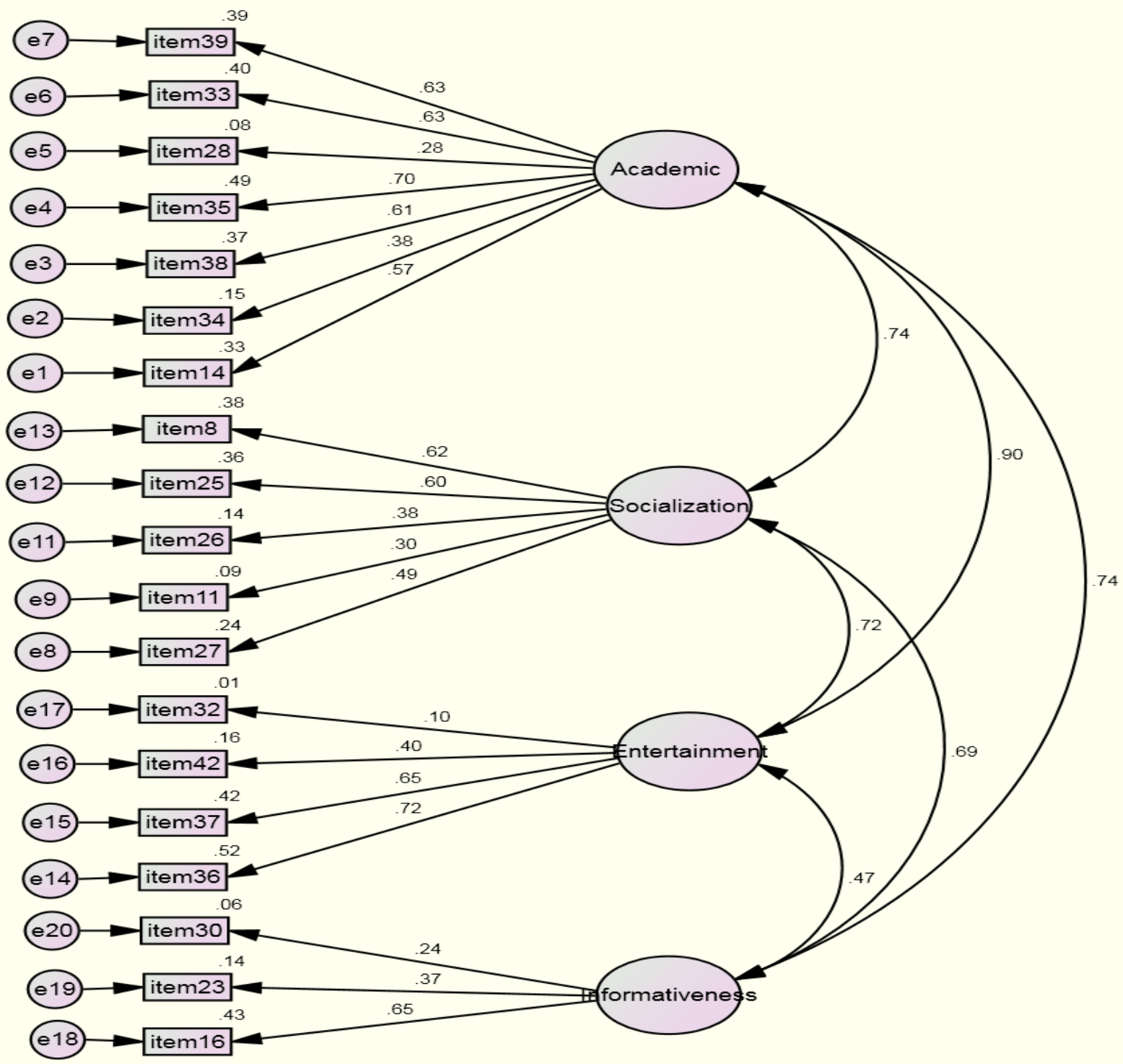

Figure 1. Confirmatory Factor Analysis 
Reliability Analysis

The Cronbach's alpha is used to measure the internal consistency among the items. According to Gliem \& Gilem (2003), the reliability coefficient Alpha normally ranges between 0 and 1 . The rule of thumb specified by George \& Mallery (2003) for interpreting Cronbach's alpha is that "above $\mathbf{0 . 8 0}$ is acceptable." Hence, the present scale Cronbach's alpha of social networking usage $(a=.830)$, indicates good internal reliability. Thus our reliability analysis suggests that social networking usage questionnaire is internally consistent. The reliability calculations are presented in Table 3.

Table 3. Reliability Statistics

\begin{tabular}{cr}
\hline Cronbach's Alpha & Number of Statements \\
\hline .830 & 19
\end{tabular}

\section{Convergent Validity}

Pearson's coefficient of correlation, calculated to identify levels of significance between factors, revealed higher levels of significant positive correlations for all dimensions of social networking usage (Academic, Socialization, Entertainment and Informativeness) with total score of social networking usage. The interrelationship of these dimensions and the total scores, calculated as suggested by Overbeek, Scholte, de Kemp, \& Engels (2007), and found to be .593 to .894 , suggest convergent validity of social networking usage questionnaire. Refer to Table 4.

Table 4. Convergent Validity of Social Networking Usage Questionnaire

\begin{tabular}{|c|c|c|c|c|c|}
\hline Measure & Academic & Socialization & Entertainment & Informativenes & $\begin{array}{l}\text { Total score } \\
\text { of social } \\
\text { networking } \\
\text { usage }\end{array}$ \\
\hline Academic & 1 & $.563 * *$ & $.558 * *$ & $.447 * *$ & $.894 * *$ \\
\hline Socialization & & 1 & $.420 * *$ & $.559 * *$ & $.783 * *$ \\
\hline Entertainment & & & 1 & $.233 * *$ & $.737 * *$ \\
\hline Informativeness & & & & 1 & $.593 * *$ \\
\hline
\end{tabular}

\section{CONCLUSION AND DISCUSSION}

The questionnaire developed in this study can help improve the measurement of university students' social networking usage in today's turbulent and changing environments. India witnessed a remarkable and rapid advancement in ICT, and Indian university students engage in online sources intensively.

The present study aimed to develop and validate a social networking questionnaire in order to understand the purposes of social networking usage of university students in an Indian context. The study draws on a broad literature review of studies measuring social networking usage in a range of educational contexts. This paper has presented the rigorous methodological procedure carried out to develop and quantitatively validate a method measuring Indian university students' social networking usage. Our scale not only has adequate statistical support but also has sufficient theoretical support. The factors extracted through exploratory factor analysis and validated through confirmatory factor analysis also have similar references in empirical studies. The "academic" factor was used 
in another study (Kio, 2016), "socialization" was used by a number of researchers (Pornsakulvanich, et al., 2013; Wijesundara, 2013; \& Park, 2015), "entertainment" was used by various researchers (Eid, et al; 2016; Griffiths 2002; Sridhar 2016, Wijesundara, 2013; \& Pornsakulvanich, et al; 2013), and finally, "informativeness" was used by Eid et al (2016), Mahajan et al (2016), Sridhar (2016), and Park (2015). Finally, the evidence of this measurement suggests that this questionnaire has robust psychometric properties to measure social networking usage among university students. This study will give academicians much needed tools and a fresh empirical perspective in their empirical research on the concept of social networking usage. Social networking and media can provide rich tools for teaching innovation and compiling ways to engage students effectively (APA, 2011). The results of previous empirical studies show that educators should embrace social media (Ito et al., 2009). Students are recommended to use it to connect with other students for group projects and homework (Boyd, 2008). Social media allow students to get together outside the class to collaborate and exchange ideas about their assignments and projects (0'Keeffe \& Clarke-Pearson, 2011). Moreover, researchers have tackled diverse ways and methods where social networking could be utilized in education. These methods included gaining more vocabulary and writing skills (Yunus et al., 2013), resources with fellow students, discussions and exchanging assignments (Asad et al., 2012), communicating, exchanging ideas with fellow students and formulating group discussions (Salvation, \& Adzharuddin, 2014).

The practical implication of the results is that the effort towards endorsing social networking usage for academia is significant in a bid to improve a sense of knowledge sharing among students, which leads to enhanced student learning. To attain this, we believe that educational institutes should work hard to organize seminars or orientation courses to encourage the positive and productive social networking attitudes and practices both by students and instructors. This study also provides some empirical evidence and guiding information for educational management staff and government professionals to better understand their social networking users' needs so that they can come up with efficient frameworks or policies.

\section{LIMITATIONS}

Even though we used highly reliable and valid scale development procedures informed by those of Henkin (1995), and Churchill (1979), there are still some limitations. The first limitation is that both the techniques of the scale refinement, of exploratory factor analysis and confirmatory factor analysis, are quite sample-size specific. This study has a rationale and proper literature support for applying these techniques, but in order to have better results a bigger sample size is advisable. The study measures four sub constructs of social networking usage, and the present scale is based on five- point Likert scale development. Further research is needed to support the discriminant, and concurrent validity. In order to validate the proof of discriminant validity, researchers should compare the shared variance in every pair of construct against the average variance extracted (Bove et al. 2009).

\section{SUGGESTIONS FOR FURTHER RESEARCH}

Given the prevalence of social networking usage in India, further research must seek to determine this questionnaire's appropriateness for use with other populations of social networking users. There are also anticipated benefits for teachers in using the scale with their university students to better understand their social networking usage. This would best be achieved by studying teacher's attitudes and opinions regarding social network use in university for academic purposes. Together, such research data might inform a more harmonized approach between students and teachers to inform situations when universities formally introduce social networking as part of their ICT solutions. A further qualitative study could be conducted based on this questionnaire to uncover the usage associated with these changes, offering insights into the patterns of use. Further research can be conducted to determine the relationship of social networking usage with the academic performance of students. 


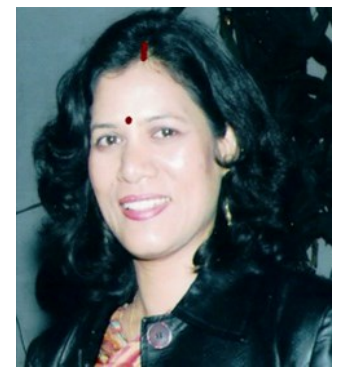

Savita GUPTA

Faculty of Education, Lovely Professional University

Jalandhar - Delhi G.T. Road, Phagwara, Punjab 144411, India

Phone: +91 9876264417

E-mail: savita,gupta@Ipu.co.in

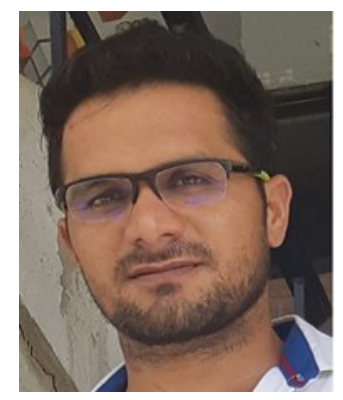

Liyaqat BASHIR is presently a PhD scholar in Department of Education, Lovely Professional University. He has completed M.Ed. \& M.Phil. in Education from Lovely Professional University (India). His area of interest in research is: Educational Psychology, Teacher education and Educational technology. He has published 10 research articles in reputed journals and 05 book chapters. Apart from attending and presenting research articles at various national and international conferences and seminars.

\section{Liyaqat BASHIR}

Department of Education, Lovely Professional University

Jalandhar - Delhi G.T. Road, Phagwara, Punjab 144411, India

Phone: +91 8825006587

E-mail: liyaqatbashir@gmail.com

\section{REFERENCES}

Abdulahi, A., Samadi, B., \& Gharleghi, B. (2014). A study on the negative effects of social networking sites such as Facebook among Asia pacific university scholars in Malaysia. International Journal of Business and Social Science, 5(10), 133-145.

Ahn, J. (2011). The effect of social network sites on adolescents' social and academic development: Current theories and controversies. Journal of the Association for Information Science and Technology, 62(8), 1435-1445.

American Psychological Association (APA) (2011). Social networking's good and bad impacts onkids. Retrieved from

http://www.sciencedaily.com/releases/2011/08/1108062038.

Andreassen, C. S., Torsheim, T., Brunborg, G. S., \& Pallesen, S. (2012). Development of a Facebook addiction scale. Psychological reports, 110(2), 501-517.

Asad, S., Al Mamun, M. A., \& Clement, C. K. (2012). The Effect of Social Networking Sites to the Lifestyles of Teachers and Students in Higher Educational Institutions. International Journal of Basic and Applied Sciences, 1(4), 498-510.

Blankenship, M. (2011). How social media can and should impact higher education. The Education Digest, 76(7), 39.

Bolar, K. P. (2009). Motives behind the use of social networking sites: an empirical study. IUP Journal of Management Research, 8(1), 75. 
Bove, L. L., Pervan, S. J., Beatty, S. E., \& Shiu, E. (2009). Service worker role in encouraging customer organizational citizenship behaviors. Journal of Business Research, 62(7), 698-705.

Boyd, D. M. (2008). Taken out of context: American teen sociality in networked publics. University of California, Berkeley.

Child, D. (1990). The essentials of factor analysis, second edition. London: Cassel Educational Limited.

Churchill, G.A. Jr (1979). A paradigm for developing better measures of marketing constructs. Journal of Marketing Research, 16, 64-73.

Deng, L., \& Tavares, N. J. (2013). From Moodle to Facebook: Exploring students' motivation and experiences in online communities. Computers \& Education, 68, 167-176.

DeVellis, R. F. (2016). Scale development: Theory and application (2nd Ed.). Thousand Oaks, CA: Sage Publications.

Dron, J. \& Anderson, T. (2007). Collectives, networks and groups in social software for ELearning. In T. Bastiaens \& S. Carliner (Eds.), Proceedings of E-Learn 2007-World Conference on E-Learning in Corporate, Government, Healthcare, and Higher Education (pp. 2460-2467). Quebec City, Canada: Association for the Advancement of Computing in Education (AACE).

Eid, M. I., \& Al-Jabri, I. M. (2016). Social networking, knowledge sharing, and student learning: The case of university students. Computers \& Education, 99, 14-27.

Ellison, N. B. (2007). Social network sites: Definition, history, and scholarship. Journal of Computer-Mediated Communication, 13(1), 210-230.

Ellison, N. B., Steinfield, C., \& Lampe, C. (2007). The benefits of Facebook "friends:" Social capital and college students' use of online social network sites. Journal of Computer-Mediated Communication, 12(4), 1143-1168.

English, R. M., \& Duncan-Howell, J. A. (2008). Facebook@ goes to college: Using social networking tools to support students undertaking teaching practicum. Journal of Online Learning and Teaching, 4(4), 596-601.

George, D. R., \& Dellasega, C. (2011). Use of social media in graduate-level medical humanities education: two pilot studies from Penn State College of Medicine. Medical Teacher, 33(8), 429-434.

George, D., \& Mallery, P. (2003). Reliability analysis. SPSS for Windows, step by step: a simple guide and reference, 14th edn. Boston: Allyn \& Bacon, 222-232.

Gliem, J. A. \& Gilem, R. R. (2003). Paper Presented at the Midwest Research-to-Practice Conference in Adult, Continuing, and Community Education, The Ohio State University, Columbus, OH, October 8-10, 2003.

Griffiths, M. D. (2002). The educational benefits of videogames. Education and health, 20(3), 47-51.

Hair, J. F. J., Black, W. C., Babin, B. J., \& Anderson, R. E. (2010). Multivariate data analysis Upper Saddle River: Pearson Prentice Hall. [Links].

Hinkin, T.R. (1995). A brief tutorial on the development of measures for use in survey questionnaires. Organizational Research Methods, 1, 104-121.

Hunter, J. E., \& Gerbing, D. W. (1982). Unidimensional measurement, second order factor analysis, and causal models. Research in Organizational Behavior, 4, 267-320.

Ito, M., Baumer, S., Bittanti, M., Cody, R., Stephenson, B. H., Horst, H. A., \& Perkel, D. (2009). Hanging out, messing around, and geeking out: Kids living and learning with new media. MIT press. 
Jenkins-Guarnieri, M. A., Wright, S. L., \& Johnson, B. (2013). Development and validation of a social media use integration scale. Psychology of Popular Media Culture, 2(1), 38.

Jöreskog, K. G., \& Sörbom, D. (2006). "LISRELS 8.80. Scientific Software International". Inc, Copyright.

Kio, S. I. (2016). Extending social networking into the secondary education sector. British Journal of Educational Technology, 47(4), 721-733.

Kuss, D. J., \& Griffiths, M. D. (2011). Addiction to social networks on the internet: A literature review of empirical research. International Journal of Environment and Public Health, 8(9), 3528-3552.

Lampe, C., Ellison, N., \& Steinfield, C. (2007). A Face(book) in the crowd: Social searching vs. social browsing. Proceedings of the SIGCHI conference on human factors in computing systems, 434-444.

Leung, L. (2002). Loneliness, self-disclosure, and ICQ (" I seek you") use. Cyber Psychology \& Behavior, 5(3), 241-251.

Likert, R. A. (1932). A Technique for the Measurement of Attitudes. Archives of Psychology. 22(140): 55. Retrieved from, http://psycnet.apa.org/psycinfo/193301885-001.

Mahajan, R., \& Bakhshi.A. (2016). Personality and subjective well-being of social network site users. Shodganga Thesis. Retrieved from http://hdl.handle.net/10603/84856.

Morahan-Martin, J., \& Schumacher, P. (2003). Loneliness and social uses of the Internet. Computers in Human Behavior, 19(6), 659-671.htt

O'Keeffe, G. S., \& Clarke-Pearson, K. (2011). The impact of social media on children, adolescents, and families. Pediatrics, 127(4), 800-804.

Park, C. S. (2015). Pathways to Expressive and Collective Participation: Usage Patterns, Political Efficacy, and Political Participation in Social Networking Sites. Journal of Broadcasting \& Electronic Media, 59(4), 698-716.

Pastor, L. (2012). Breaking boundaries in entertainment and learning. eLearn Center Research Paper Series, (5), 06-13.

Pempek, T. A., Yermolayeva, Y. A., \& Calvert, S. L. (2009). College students' social networking experiences on Facebook. Journal of applied developmental psychology, 30(3), 227-238.

Pornsakulvanich, V., \& Dumrongsiri, N. (2013). Internal and external influences on social networking site usage in Thailand. Computers in Human Behavior, 29(6), 27882795.

Prensky, M. (2001). Digital natives, digital immigrants part 1. On the horizon, 9(5), 1-6.

Ross, C., Orr, E. S., Sisic, M., Arseneault, J. M., Simmering, M. G., \& Orr, R. R. (2009). Personality and motivations associated with Facebook use. Computers in human behavior, 25(2), 578-586.

Salvation, M., \& Adzharuddin, N. A. (2014). The influence of social network sites (SNS) upon academic performance of Malaysian students. International Journal of Humanities and Social Sciences, 4(10), 131-137.

Shi, Y., Luo, Y. L., Yang, Z., Liu, Y., \& Cai, H. (2014). The Development and Validation of the Social Network Sites (SNSs) Usage Questionnaire. In International Conference on Social Computing and Social Media (pp. 113-124). Springer, Cham.

Shin, N. Y., \& Lim, Y. J. (2017). Development and Validation of a Social Network Site Use Motives Scale for College Students in South Korea. Journal of Psychoeducational Assessment, 35(3), 1-8. 
Sridhar, P., \& Vizhi, T.K. (2016).A study on advertising in social networking sites and its implications on consumer buying behavior. Indian journal of research parafix, 5(8), 200-203.

Srivastava, P. (2012). Social Networking \& Its Impact on Education-System in Contemporary Era. International Journal of Information Technology Infrastructure, 1(2).

Subrahmanyam, K., Reich, S. M., Waechter, N., \& Espinoza, G. (2008). Online and Offline Social Networks: Use of Social Networking Sites by Emerging Adults. Journal of Applied Developmental Psychology, 29 (6), 420-433.

Suhr, D. D. (2006). Exploratory or confirmatory factor analysis? (pp. 1-17). Cary: SAS Institute.

Tabachnick, B.G. and Fidell, L.S. (1996). Using Multivariate Statistics 3rd ed. HarperCollins College, New York, NY.

U.S. Department of Education. (2009). Evaluation of evidence-based practices in online learning: A meta-analysis and review of online learning studies. Washington, D.C.: U.S. Department of Education, Office of Planning, Evaluation, and Policy Development.

Unachukwu, G. O., \& Emenike, C. B. (2016). Online social network usage and influence on academic achievement of secondary school students in anambra state, Nigeria. Implications for school administrators. International Educational Scientific Research Journal, 2(8), 10-12.

Wiberg, M. (2007). Netlearning and learning through networks. Journal of Educational Technology \& Society, 10(4), 49-61.

Wijesundara, T. R. (2013). Motivations and usage patterns of social networking sites: Exploring cultural differences between United States \& Sri Lanka (Master's thesis, University of Agder).

Wilson, S. M., \& Peterson, L. C. (2002). The anthropology of online communities. Annual review of anthropology, 31(1), 449-467.

Yunus, M. M., Nordin, N., Salehi, H., Embi, M. A., \& Salehi, Z. (2013). The use of information and communication technology (ICT) in teaching ESL writing skills. English Language Teaching, 6(7), 1-8. 


\section{APPENDIX}

Please fill up the following information:

SOCIAL NETWORKING USAGE QUESTIONNAIRE

Name

Class

Age

Gender

Urban/Rural

Stream: Arts/Science/Commerce

Name of College/University

Previous Exam Marks

Previous Exam Percentages

INSTRUCTIONS

This is a questionnaire that attempt to measure the social networking usage of an individual. The items of the scale are given in statement form. You are requested to read each statement carefully and give your response by putting a tick $(\checkmark)$ mark only that option which you find that is most appropriate and true in your case. There is no right / wrong answer.

Example:

Always Often Sometimes

Rarely Never

I use social networking sites for sharing pictures.

In the above statement, if you feel the correct response could be Always, then put tick $(\checkmark)$ in that column. Please do not leave any statement unattempt. There is no time limit. Your responses will be used for research purpose only and the responses will be always kept confidential.

\begin{tabular}{|c|c|c|c|c|c|c|}
\hline Sr & Statements & Always & Often & Sometimes & Rarely & Never \\
\hline 01 & I use social networking sites to become more sociable. & & & & & \\
\hline 02 & $\begin{array}{l}\text { I use social networking sites to keep in touch with my } \\
\text { relatives. }\end{array}$ & & & & & \\
\hline 03 & $\begin{array}{l}\text { I use social networking sites to seek help from my } \\
\text { teachers. }\end{array}$ & & & & & \\
\hline 04 & $\begin{array}{l}\text { I use social networking sites for getting jobs related } \\
\text { information. }\end{array}$ & & & & & \\
\hline 05 & I use social networking sites to share new ideas. & & & & & \\
\hline 06 & $\begin{array}{l}\text { I use social networking sites to create my social } \\
\text { identity. }\end{array}$ & & & & & \\
\hline 07 & $\begin{array}{l}\text { I prefer using social networking sites to attending } \\
\text { social gathering. }\end{array}$ & & & & & \\
\hline 08 & $\begin{array}{l}\text { I use social networking sites to get information } \\
\text { regarding current social events. }\end{array}$ & & & & & \\
\hline 09 & $\begin{array}{l}\text { I use social networking sites for online academic } \\
\text { group discussion. }\end{array}$ & & & & & \\
\hline 10 & I use social networking sites for reading news. & & & & & \\
\hline 11 & I use social networking sites for sharing pictures. & & & & & \\
\hline 12 & I use social networking sites to do research work. & & & & & \\
\hline 13 & $\begin{array}{l}\text { I use social networking sites to learn about my } \\
\text { curricular aspect. }\end{array}$ & & & & & \\
\hline 14 & $\begin{array}{l}\text { I communicate with my friends via social networking } \\
\text { sites for preparation of exam. }\end{array}$ & & & & & \\
\hline 15 & $\begin{array}{l}\text { I use social networking sites to get relief from } \\
\text { academic stress. }\end{array}$ & & & & & \\
\hline 16 & I use social networking sites for watching movies. & & & & & \\
\hline 17 & $\begin{array}{l}\text { I use social networking sites for collaborative } \\
\text { learning. }\end{array}$ & & & & & \\
\hline 18 & $\begin{array}{l}\text { I use social networking sites to solve my academic } \\
\text { problem. }\end{array}$ & & & & & \\
\hline 19 & I use social networking sites to look at funny sharing. & & & & & \\
\hline
\end{tabular}

